


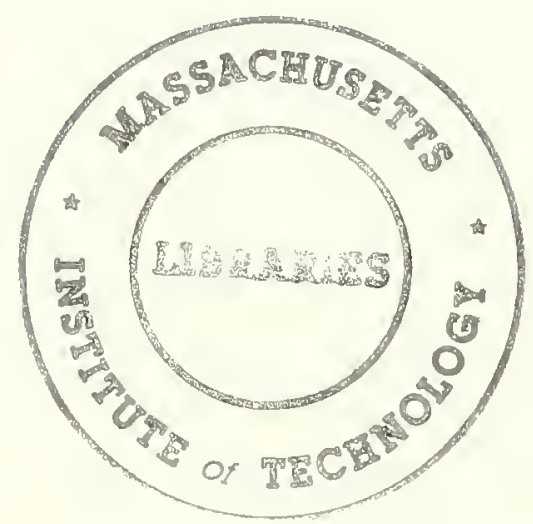




\section{Digitized by the Internet Archive in 2011 with funding from Boston Library Consortium Member Libraries}





\section{working poper department of economics}

\section{Robert Gibbons \\ Kevin J. Murphy}

RELATIVE PERFORMANCE EVALUATION

FOR CHIEF EXECUTIVE OFFICERS

No. 532

\section{massachusetts instifute of technology}

50 memorial drive cambridge, mass. 02139 

RELATIVE PERFORMANCE EVALUATION

FOR CHIEF EXECUTIVE OFFICERS

Robert Gibbons

kevin J. Murphy

No. 532

Auguse 1989 


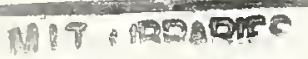

DEC \& 1989

AECENE! 


\title{
RELATIVE PERFORMANCE EVALUATION FOR CHIEF EXECUTIVE OFFICERS*
}

\author{
Robert Gibbons \\ MIT and NBER \\ Kevin J. Murphy \\ University of Rochesser \\ August, 1989 \\ (forthcoming, Industrial and Labor Relations Revicw, 1990)
}

Abstract

Measured individual performance often depends on random factors which also affect the performances of other workers in the sane firm, industry, or market. In these cases, relative performance evaluation (RPE) can provide incentives while partially insulating workers from the common uncertainty. Basing pay on relative performance, however, generates incentives to sabotage the measured performance of co-workers, to collude with co-workers and shirk, and to apply for jobs with inept co-workers. RPE contracts also are less desirable when the output of co-workers is expensive to measure or in the presence of production externalities, as in the case of team production.

The purpose of this paper is to review the benefits and costs of RPE and to test for the presence of RPE in one occupation where the benefits plausibly exceed the costs: toplevel management. Rewarding chief executive officers (CEOs) based on performance measured relative to the industry or market creates incentives to take actions increasing shareholder wealth while insuring executives against the vagaries of the stock and product markets that are beyond their control. We expect RPE to be a common feature of implicit CEO compensation and dismissal contracts because the potential benefit of filtering out common uncerainty is high, the cost of measuring the performance of other firms is small, and opportunities for sabotage and collusive shirking are limited.

In contrast to previous research, bur empirical evidence strongly suppors the RPE hypothesis-CEO pay revisions and retention probabilities are positively and significantly related to firm performance, but are negatively and significantly related to industry and market performance, ccteris paribus. Our results also suggest that CEO performance is more likely to be evaluated relative to aggregate market movements than relative to industry movements.

- We are grateful for many helpful comments from John Abow'd, Joshua Angrish James Brickley, David Card. Jeffrey Coles, Ronald Ehrenberg. Henry Farber, Lawrenec Kalz, Alan Krueger, Edward Lazcar, Meg Meyer, Sherwin Rosen, Sharon Smith, Ross Watus, and Mfichacl W'cisbach as w'cll as from paricipants in seminars at NBER, NYU, and the Princeton Labor Lunch. This research is supported by the Sloan Foundation (both authors); the NSF (grant SES 88-09200) and the Industrial Relations Section at Princeton University (Gibbons); and the John M. Olin Foundation and the Managcrial Economics Rescarch Cenier, University of Rochesier (Murphy'). 



\section{RELATIVE PERFORMANCE EVALUATION FOR CHIEF EXECUTIVE OFFICERS}

Rober Gibbons and Kevin J. Murphy

It is common for workers to be rewarded not simply for their own performance but rather for their performance measured relative to the performances of co-workers. Examples are explicit contests and toumaments, the allocation of a fixed bonus pool at thecorporate or divisional level, forced-distribution performance appraisals, and promotions awarded to one worker from a group of subordinates.

Economic theory provides a rationale for relacive performance evaluation (RPE) based on risk-sharing. Compensation based solely on observed individual. performance provides incentives for a worker to be productive, but measured performance (and therefore compensation) is almost always affected by random factors beyond the worker's control. The random factors which affect one worker's performance often affect the observed performances of other workers in the same division, firm, industry, or market. In these cases, RPE can provide incentives while partially insulating the worker from the common uncertainty.

Although RPE offers bencfits when there exists an important source of common risk or

uncertainty, it also entails costs. Basing pay on relative performance generates incentives to sabotage the measured performance of co-workers (or any other reference group), to collude with co-workers and shirk, and to apply for jobs with inept co-workers. Relative-performance contracts also are less desirable when the output of co-workers is expensive to measure or when there are production externalities, as in the case of team production.

One occupation for which the risk-sharing advantages of RPE likely exceed its counterproductive side-effects is top-level corporate management. Executive compensation contracts based only on firm performance subject executives to vagaries of the stock and product markets that are clearly beyond management control. Measuring managerial performance relative 
to the performance of other firms in the same industry or market partially insulates executives from such industry and market shocks. Relative-performance contracts for chief executive officers (CEOs) are inexpensive to administer, since the stock performance of rival firms is available on a daily basis at trivial cost. In addition, because CEOs tend to have limited interaction with CEOs in rival firms, sabotage and collusive shirking seem unlikely.

The purpose of this paper is to investigate empirically the extent to which CEOs are rewarded on the basis of relative performance. We begin with a review of the benefits and costs of RPE in the workplace, and then apply the analysis to the case of top-level management. We test for the presence of RPE in executive compensation by analyzing a longitudinal sample of over 1,600 CEOs from more than one thousand publicly held corporations.

This paper builds on previous research in agency theory, especially Holmström (1982), who developed the economic theory of relative performance evaluation, and Antle and Smith (1986), who tested for the existence of RPE in executive compensation contracts. We extend Holmström's analysis by discussing the costs as well as the benefits of relative-performance contracts. Our debt to other related research is discussed below.

\section{The Theory of Relative Performance Evaluation}

\section{A Simple Model of the Benefits of RPE}

This section presents an informal review of the economic theory of relative performance evaluation. Early papers on this subject include Baiman and Demski (1980) and Lazear and Rosen (1981); Wolfson (1985) applies the theory to shared-equiry real estate contracts. The analysis in this section applies to all employees in a workplace; we defer our application of the theory to top-level management until the next section.

Suppose that output, $y$, depends on the worker's effort, a, but is stochastic. For example, 


$$
y=a+\varepsilon
$$

where $\varepsilon$ is a noise term with zero mean. Because the worker's effort is unobservable, the employer and worker cannot sign a contract specifying that the employee supply a paricular level of effort. Instead, the employer offers the worker a compensation contract, $w(y)$, that determines the worker's wage as a function of the realized output of the production process. The worker then chooses whether to sign the contract or to take up alternative employment yielding utility U0. After signing the contract, the worker chooses a level of effort, and production occurs.

Suppose that the employer is risk-neutral: he cares only about output net of compensation, $y-w$. The worker, on the other hand, dislikes effort and is averse to compensation risk. Under these assumptions, full efficiency (the "first-best") is defined by two conditions: (a) the worker must supply the productively efficient level of effort (that is, the level of effort at which the expected value of the output resulting from an additional unit of effort equals the disutility to the worker from this additional unit of effor); and (b) the worker must be perfectly insured against compensation risk.

If the worker were risk-neutral, insurance would be unnecessary and the first-best could be achieved via a contract $w(y)=y-F$ that, in effect, sells the worker the firm: the worker receives the entire output, $y$, as compensation, but pays the cmployer an up-front fee, $F$, so that the worker's expected utility just equals his reservation utility. When workers are risk-averse, however, the optimal contract is necessarily "second-best," both because the worker bears income risk and because the worker's effor choice is smaller than is productively efficient. The optimal contract for a risk-averse worker reflects a trade-off between the goals of insuring the worker and providing incentives for efficient effort choice.

The fact that the best possible contract of the form $w(y)$ induces a risk-averse worker to supply less than the productively efficient amount of effort suggests that employers may be able to improve the contract by making pay contingent on a second variable, $z$, in addition to output, y. Holmström (1979) showed that the optimal contract has the form $w(y, z)$ whenever $z$ contains 
incremental information valuable in assessing the worker's unobservable effor. ${ }^{1}$ The intuition for including $z$ in the contract $w(y, z)$ is either to provide more insurance without reducing incentives for effort or to provide greater incentives without increasing risk exposure.

As a concrete example, suppose that the worker's output depends not only on effort and idiosyncratic noise, $\varepsilon$, but also on an additional noise term, $\theta$, where $\theta$ is a common shock experienced by some set of workers in the same division, firm, industry, or market:

$$
y=a+\varepsilon+\theta
$$

The shock $\theta$ could reflect seasonal or random variations in industry demand, märkêt-wide stock movements, or the fixed-effect of a single supervisor evaluating each member of a group of workers, among other possibilities. If $\theta$ is perfectly observable, contracts of the form $w(y-\theta)$ clearly improve on contracts of the form $w(y)$. The presence of $\theta$ makes $y$ a noisier signal about effort than it would be in the absence of $\theta$. Therefore, the employer can reduce the noise in his evaluation of the worker's effort by basing contracts on $y-\theta$ rather than on $y$ alone. Even if the common shock $\theta$ is not perfectly observable, the employer still can improve on contracts of the form $w(y)$ by incorporating an estimate of $\theta$, denoted by $\hat{\theta}$, into the contract. Since $\hat{\theta}$ measures the common shock $\theta$ with error, optimal contracts incorporating the estimate $\hat{\theta}$ will generally be of the form $w(y, \hat{\theta})$ rather than of the simpler form $w(y-\hat{\theta})$, and the common risk will be only partially filtered out of the worker's compensation.

To see how $\hat{\theta}$ might be computed, consider the following elaboration of the example above. ${ }^{2}$ Suppose that there are $n$ identical workers whose outputs are given by $y_{i}=a_{i}+\varepsilon_{i}+\theta_{\text {, }}$ for $\mathrm{i}=1, \ldots, \mathrm{n}$, where $\mathrm{a}_{\mathrm{i}}$ and $\varepsilon_{\mathrm{i}}$ are the $\mathrm{i}^{\text {th }}$ worker's effort and idiosyncratic noise, respectively. Then, assuming that the $\varepsilon_{i}^{\prime}$ 's are independently and identically distributed with zero mean, an estimate of the common shock is $\hat{\theta}=\bar{y}-\bar{a}$, where $\bar{y}$ is the average output of all other workers subject to the common shock $\theta$, and $\bar{a}$ is the average anticipated effort level of these $n-1$ other

1 More precisely, the optimal contract will depend on $z$ if $y$ is not a sufficient statistic for the pair $\{y, z\}$ with respect to the worker's effor.

2 Aliemative methods of calculating $\hat{\theta}$ applicable to special siluations include seasonal adjustments and prorating output to adjust for unanticipaled plant closings. 
workers conditional on their compensation packages. ${ }^{3}$ Under the assumption that the $\varepsilon_{\mathrm{j}}$ 's are normally distributed, Holmström (1982) showed that the optimal contract for the $i^{\text {th }}$ worker is $w_{j}\left(y_{i}, \bar{y}\right) .^{4}$ Typically, the wage paid to the $i^{\text {th }}$ worker will be positively related to his ow'n ouput but negatively related to the average output of all other workers subject to the same common shock. Holmström also showed that as the number of workers becomes very large (so that $\hat{\theta}$ is a very precise estimate of 0 ), the optimal contract approaches the form $w_{i}\left(y_{i}-\bar{y}\right)$, where $y_{i}-\bar{y}$ is the performance of the $\mathrm{i}_{\text {th }}$ worker measured selative to the performance of others in the reference Eroup.

Relative performance evaluation may be beneficial even in the absence of risk-aversion and incentive problems. Alternative models based on leaming about ability rather, for example, also predict RPE when workers in a group are exposed to a common shock. Formally, let individual output, $y_{i}$, depend on ability and not effort:

$$
y_{i}=\eta_{i}+\varepsilon_{i}+\theta,
$$

where $\eta_{\mathrm{i}}$ is the $\mathrm{ith}$ worker's ability, $\varepsilon_{\mathrm{i}}$ is idiosyncratic noise, and $\theta$ is the unobservable common shock. Suppose that ability is not known precisely; rather, $\eta_{\mathrm{i}}$ is believed to be normally distributed with mean zero and variance $\sigma_{\eta}{ }^{2}$. (Allowing for a non-zero mean is straightforward but uninformative.) Suppose further that $\theta$ and $\varepsilon_{\mathrm{i}}$ are normally distributed with mean zero and variances $\sigma_{\theta}{ }^{2}$ and $\sigma_{\mathcal{\varepsilon}}{ }^{2}$, respectively, and that the common shock and the $\mathrm{n}$ workers' individual abilities and noise terms are independent. Given these assumptions, it is straightforward to show (see, for example, Theorem 9.11 of Mood and Graybill, 1963) that the expected ability of the ith worker, given his output and the outputs of the n-1 co-workers subject to the shock $\theta$, is as described by equation (4).

3 The estimate in the text, $\hat{\theta}=\bar{y}-\bar{a}$, is the OLS escimate of $\theta$ given the available information about the $n-1$ other workers. A more efficient OLS estimate of $\theta$ would also include the information available about the $i^{\text {th }}$ worker. If the joint distribution of the idiosyncratic noise terms is known, one can also compute the maximum likelihood estimate of $\theta$. Onc can relax the assumption that the idiosyncratic noise terms are independently and identically distributed.

4 Note that $y_{i}$ plays two roles in this contract. First, it provides incentives in the usual way. Second, it improves the estimate of $\theta$ as described in footnote 3 . 


$$
E\left[\eta_{i} \mid y_{1}, \ldots, y_{n}\right]=\frac{\sigma_{\eta}^{2}}{\sigma_{\eta}^{2}+\sigma_{\varepsilon}^{2}}\left(y_{i}-\frac{\sigma_{\theta}^{2}}{\sigma_{\eta}^{2}+\sigma_{\varepsilon}^{2}+n \sigma_{\theta}^{2}} \sum_{j=1}^{n} y_{j}\right) .
$$

Suppose that individual outputs are obscrvable and that wages are a function of expected ability. Then the wage offered to the $i^{\text {th }}$ worker will typically be positively related to his own output but negatively related to the average output of all other workers subject to the same common shock.

In both the incentive model and the learning model, RPE provides a way to filter common risk from workers' compensation contracts. The qualitative predictions of (and'underlying economic rationales behind) both models are similar enough that we make no attempt to distinguish between these complementary theories of RPE.

\section{Disadvantages of Rewarding Workers Based on Relative Performance}

The benefits of RPE are straightforward-the risk exposure of risk-averse workers can be reduced by filtering out some or all of the common risk. This rationale for basing rewards on relative performance rather than on absolute performance accords with the general rule-of-thumb that workers should not be rewarded or punished for "things beyond their control." Before embracing the theory completely, however, we must also consider the costs of compensation systems based on relative performance.

An obvious cost of RPE is the cost of observing the average output of the workers subject to the same common shock. If the cost of measuring $\bar{y}$ is a fixed cost, $C$, it affects whether or not a firm uses RPE at all but does not affect the importance of relative performance in compensation contracts that use RPE: firms will use relative performance if $C$ is less than the increased value of the best contract $w_{i}\left(y_{i}, \bar{y}\right)$ relative to the best contract $w_{i}\left(y_{i}\right)$. Altematively, the size of the reference group may be a choice variable for employers-employers will sample additional workers from the pool of workers subject to the common shock as long as the incremental gain from improved contracts (associated with more precise estimates of $\theta$ ) exceeds the cost of measuring an additional worker's output. 
There is another set of costs associated with RPE that may be much more important than the simple measurement costs described above. Paying workers based on relative performance, $y_{i}-\bar{y}$, instead of on absolute performance, $y_{i}$, distorts the worker's incentives whenever the worker can take actions that affect the average output of the reference group, $\bar{y}$. Therc are at least four ways in which a worker's action can have this kind of effect: sabotage (in which the worker takes unproductive actions to diminish the measured performance of another worker in the reference group); collusion (in which workers in the same reference group collude and shirk); choice of reference group (in which a worker chooses which of several groups of other workers to which to be compared); and production externalitics (in which the productive actions of one worker affect the outputs of other workers).

Sabotage ranges from relatively subtle forms - such as concealing relevant information from, or spreading false gossip about, a fellow employee-to outright theft or destruction of coworker output. Sabotage can be cffective even if it diminishes one's ow'n output provided that it has a larger negative effect on the average output of other workers. Lazear (1987) argues that the sabotage-related problems of RPE may be a driving force in the pay equality observed in many organizations. According to Lazear, reducing pay differences based on relative performance reduces uncooperative behavior that is detrimental to the firm. Withholding valuable comments on a colleague's paper or deleting data from a colleague's hard disk are examples of potential sabotage in academia.

Rewards based on relative performance also generate incentives for workers to collude and supply less effor than would be supplied in the absence of collusion (see Mookherjee 1984 and Dye 1984). In academia, for example, colleagues could agree not to work at night, on weekends, or during summers. The general conditions for cartel stability in the product market (Stigler 1964) apply to a workplace carel as well-collusion is more likely when the number of potential colluders is small, for example, and collusion is more effective when workers can observe the output and compensation of co-workers. It seems plausible that collusion in the workplace is more likely to be stable than collusion in the product market will be, both because 
workplace collusion is not an antitrust violation and because it may be easier to monitor coworkers who are close at hand than to monitor the costs and outputs of geographically dispersed rival firms.

Relative performance evaluation also distorts incentives when agents can influence the determination of which of several possible reference groups is used in the evaluation process. Workers are often involved in interviewing, selecting, and recruiting potential colleagues. Workers paid on the basis of relative performance clearly have an incentive not to hire rookies of superior ability, and will instead desire incompetent co-workers. For example, Carmichael (1988) argued that non-tenured faculty have incentives to recruit less-able colleagues. The same rationale also applies to job search-RPE generates incentives for workers to self-select into firms with inferior co-workers. Dye (1988) argued that paying top executives based on industryrelative performance yields incentives to locate in industries with inept rivals, so that the manager appears to be both talented and hard-working relative to other managers in the (carefully selected) reference group. Similarly, RPE may adversely affect an executive's decision to leave a declining industry, and may cause a mediocre performer to leave a rapidly growing industry even if staying in the industry maximizes the value of the organization.

Finally, RPE will be less desirable when the effort levels of individual workers are complementary factors in the firm's production process, as in team production, for example. Workers paid on the basis of relative performance will not have incentives to develop innovations that uniformly increase the productivity of all other workers in the reference group. Optimal contracts in the presence of such production externalities typically involve rewarding individuals for group output, $\partial w_{i}\left(y_{i}, \bar{y}\right) / \partial \bar{y}>0$, instead of rewarding individual performance measured relative to the performance of others, $\partial w_{i}\left(y_{i}, \bar{y}\right) / \partial \bar{y}<0$.

The costs and benefits of RPE suggest that filtering out common risk will be more effective in some situations than in others. Incentives to sabotage or collude with other agents subject to the same common shock are more imporant when the number of co-workers is small, and RPE will therefore be less effective for small groups than for large groups, ceteris paribus. 
Also, RPE will be more effective when the worker is unable to influence the choice of reference group, and will be less effective when there are externalities in the production process (such as team production), or when the output of co-workers is expensive to measure.

\section{Rewarding Executives on Relative Performance}

The relationship between the shareholders of a publicly owned corporation and the corporation's top manager is an archetypal example of a principal-agent relationship. Widely diffuse shareholders, assumed to be well diversified and therefore risk-neutral, want the manager to take actions that increase shareholder wealth. The imperfectly monitorable manager, however, takes actions that increase his expected utility. Managerial contracts tying pay and dismissal decisions to changes in shareholder wealth help align the intcrests of shareholders and the manager by giving the manager incentives to take actions that increase shareholder wealth.

Although the change in shareholder wealth is an appropriate measure of managerial output or firm performance, it is an imperfect measure of managerial effort, since many factors affect the value of a firm besides the actions taken by managers. (Managerial effort in this context refers not to how hard an executive works but rather to whether or not he takes actions or makes decisions that increase shareholder wealth.) Executives facing contracts based only on changes in shareholder wealth are subject to vagaries of the stock and product markets that are clearly beyond management control. The theory of relative pefformance evaluation suggests that optimal managerial contracts may base compensation and dismissal decisions on performance relative to other firms in the industry or market in order to filter common risk from the compensation of risk-averse managers.

Top-executive compensation and dismissal policy seems a likely place to observe RPE. First, it seems plausible that industry or market shocks (such as the October 1987 stock-market crash) are important and that filtering out these shocks can benefit risk-averse executives. Second, although there are of course important problems related to defining an industry, 
measuring the stock-market performance of other firms in a defined industry is easily accomplished on a daily basis at trivial cost. Third, because CEOs tend to have limited interaction with CEOs in rival firms, the potential for sabotage, collusive shirking, and production externalities is probably small. Another source of distorted incentives, the choice of a reference group, may be important, however (to the extent that the CEO plays a key role in choosing the industry in which his firm competes): under RPE, a manager who is among the best CEOs in a declining industry will not have the correct incentives to leave the industry. Finally, there may be production externalities across firms: for example, RPE makes oligopolistic collusion more difficult to sustain.

Another way to filter risks associated with industry and market shocks is to pay (or dismiss) executives in a given firm on the basis of their performance measured relative to the performance of other executives in the same firm. Lazear and Rosen (1981), for example, argue that top-management promotions are a form of RPE in which the vice president with the highest measured output is promoted to CEO. It is precisely this type of situation, however, in which the costs of RPE may be large. First, there are typically only a small number of vice presidents with a non-trivial chance of winning the promotion toumament, and therefore the opporunities for sabotaging or colluding with rival vice presidents seems large. Also, CEOs typically play an important role in selecting the team of vice presidents as well as their ultimate successor (Vancil 1987), so a CEO paid on the basis of his performance measured relative to the performance of subordinates may believe he can hold his position longer if he chooses incompetent vice presidents. Finally, because firm output (in this case, changes in shareholder wealth) is presumably jointly produced by the top management team, RPE may interfere with the shareholder's objective of maximizing team production. 


\section{Relative Performance and CEO Compensation}

We test the imponance of RPE in cxecutive compensation and dismissal decisions by following all chief executive officers listed in the Executive Compensation Surveys published in Forbes from 1974 to 1986. These surveys include 2,214 executives serving in 1,295 corporations, or a total of 10,400 CEO-years of data. We focus on the CEO's compensation and dismissal rather than on his total incentives (which are created not only by compensation and threat of dismissal but also by changes in the value of his outstanding stock options and of his inside stockholdings) because changes in the value of previous holdings of stock and stock options are determined entirely by firm performance, independent of selative performance. Thus, if relative performance is important, its imponance must arisc in compensation and dismissal policy. We examine RPE in executive compensation contracts in this section; dismissals based on relative performance are cxamined in the next section.

We measure firm performance as the change in the logarithm of shareholder wealth, which equals the continuously accrued rate of return received by the firm's shareholders, including price appreciation and dividends. Reference-group stock-market performance is measured using the population of 11,000 firms listed on the Compustat expanded industrial, full coverage, and historical research files. Several potential reference groups are analyzed: the entire Compustat population ("the market") and firms in the same one-, two-, three-, and fourdigit SIC industries as the sample firm. Industry return is defined as the continuously accrued rate of return realized on a value-weighted porfolio of all Compustat firms (excluding the sample firm) in the same SIC industry; market return is the continuously accrued return on the valueweighted portfolio of all Compustat firms (excluding the sample firm).

Stock retums for New York Stock Exchange (NY'SE) firms are calculated using fiscalyear stock-market data available from the Center for Research in Security Prices (CRSP). Fiscalyear industry classifications for NYSE and American Stock Exchange firms are also obtained 
from CRSP. Compustat industry classifications and stock data are used for firms included in Compustat files but not on CRSP files. ${ }^{5}$ After matching these performance variables with the Forbes compensation sample and eliminating observations with missing data, our final sample contains 9,425 observations and includes 1,668 executives from 1,049 corporations. All rates of return and monetary variables are adjusted for inflation (using the consumer price index for the closing month of the fiscal year) to represent 1986-constant dollars.

Agency theory predicts that compensation will depend on absolute or relative performance but gives little guidance as to the form of the contract. We estimate the following relation between pay and firm, industry, and market performance:

$$
\Delta \ln (\text { CEO Pay })=\alpha+\beta(\text { Sharcholder Return })+\gamma(\text { Industry and/or Market Return }) .
$$

Rewarding CEOs for taking actions that increase shareholder wealth implies that $\beta>0$. RPE implies that, holding the firm's rate of return constant, CEO pay revisions should be negatively related to the industry and market return, $\gamma<0$.

Table 1 reports estimated coefficients from regressions relating the growth rate of CEO salary and bonus to the rates of return realized by shareholders in the firm, iwo-digit SIC industry, and market. Column (1) shows that CEO salaries and bonuses are positively and significantly related to firm performance as measured by the rate of retum on common stock. The retum coefficient of $1562(t=19.5)$ implies, for example, that CEO pay changes by about $1.6 \%$ for each $10 \%$ retum on the common stock. 6

Note that we interpret our estimate as having identified a compensation formula, rather than a causal relation from the compensation formula to observed performance. The latter inter-.

5 Compustat industry designations are appropriate only for the current or final year (generally 1987), whereas CRSP data allow the firm's industry to change from year to year. Compustat stock reurns are based on calendaryear and not fiscal-year data, but when we replicated our analysis (including the construction of industry retums) for the subset of firms with December fiscal closings, our results were qualitatively unchanged.

6 The estimated sctum cocfricient in column ( 1 ) is highly significant, but its economic magnitude is small. The sample medians for CEO pay and firm size (measured by market value) are $\$ 465,000$ and $\$ 812,000,000$, respectively. Thus, a $10 \%$ retum in a median-size firm is $\$ 81,200,000$ and corrcsponds 10 a pay raise for the median-pay CEO of $\$ 7,300$, or less than nine cents for each $\$ 1,000$ of increased sharcholder wealth. See Jensen and Murphy (1990) for further discussion of the magnitude of the empirical relation between pay and performance. 
TABLE I

Coefficients of Ordinary Leası Squares Regressions of $\triangle \ln$ (CEO Salary + Bonus) on Firm. Industry, and Market Rates of Return on Common Sinck

( 1 -statistics in parentheses)

\begin{tabular}{|c|c|c|c|c|c|}
\hline \multirow[t]{2}{*}{$\begin{array}{l}\text { Independent } \\
\text { Variable }\end{array}$} & \multicolumn{2}{|c|}{ Dependent Variable: } & \multicolumn{3}{|c|}{$\Delta \ln ($ CEO Salary + Bonus $)$} \\
\hline & (1) & (2) & (3) & & (4) \\
\hline Intercept & .046 & .055 & .068 & & .068 \\
\hline $\begin{array}{l}\text { Firm's Rate of Retum } \\
\text { on Common Stock }\end{array}$ & $\begin{array}{l}.1562 \\
(19.5)\end{array}$ & $\begin{array}{l}.1781 \\
(19.4)\end{array}$ & $\begin{array}{l}.1805 \\
(21.0)\end{array}$ & & $\begin{array}{l}.1824 \\
(19.9)\end{array}$ \\
\hline $\begin{array}{l}\text { 2-Digit SIC Industry } \\
\text { Value-Weighted Retum }\end{array}$ & - & $\begin{array}{l}-.0750 \\
(-4.9)\end{array}$ & - & - & $\begin{array}{c}-.0112 \\
(-0.6)\end{array}$ \\
\hline $\begin{array}{l}\text { Market Value-Weighted } \\
\text { Retum on Common Stock }\end{array}$ & - & - & $\begin{array}{l}-.1490 \\
(-7.6)\end{array}$ & & $\begin{array}{c}-.1407 \\
(-5.8)\end{array}$ \\
\hline$R^{2}$ & .0467 & .0496 & .0537 & & .0538 \\
\hline
\end{tabular}

pretation would be incorrect, because it ignores the role of the capital market in bidding up the stock price to reflect a firm's expected profit. That is, although it is true that a higher piece rate (for example) will induce more effor and so improve expected future profits, the stock price will adjust for this effect on the day the piece rate is announced, well before future profits are observed. Subsequent movements in our independent variable, the furm's rate of retum, are thus independent of the compensation formula in place.

The estimated coefficient for industry rate of retum in column (2) of Table 1 is negative and statistically significant, suggesting that boards of directors make some adjustment for industry trends when determining executive compensation. The coefficients in column (2) suggest, for example, that a CEO receives an average pay increase of $5.5 \%$ in years when shareholder return is zero in both the firm and the industry. The same CEO receives an average pay increase of $9.1 \%$ in years when shareholder return is $20 \%$ and industry return is zero, but receives an increase of only $7.6 \%$ in years when all firms in the industry realize $20 \%$ rates of 
return. This result is consistent with the hypothesis that uncertainties shared with other firms are partially filtered out of the CEO's compensation contract. ${ }^{\text {? }}$

Column (3) of Table 1 reports coefficients from regressions of CEO pay growth on shareholder return and the rate of return in the market. The negative and significant marketreturn coefficient suggests that market risks are also partially filtered out of executive compensation. The explanatory power of column (3) exceeds that of column (2), suggesting that CEO compensation contracts are more closely linked to market-relative returns than to two-digit industry-relative returns. The regression in column (4) includes both industry and market returns. The market-return coefficient is negative and statistically significant, indicating that CEOs are rewarded on the basis of market-relative performance and not only on absolute performance. The industry-return coefficient is no longer significant after controlling for marketwide stock-price movements, although the point estimate is still negative.

The theory of RPE suggests that common uncertainties will be filtered out of executive compensation, but is of course silent on whether industry or market uncertainties are the most important source of common risk. The results in column (4) of Table 1 suggest that CEO performance is more likely to be evaluated relative to aggregate market movements than relative to industry movements, where the industry is defined as all other firms in the same two-digit SIC industry. We explore the robustness of this conclusion by re-estimating columns (2) and (4) of Table 1 for three alternative industry definitions: one-digit, three-digit, and four-digit SIC industries. Results from these regressions are presented in Table 2.

Columns (1), (2), and (3) of Table 2 show that CEO pay growth is positively related to shareholder retum and negatively related to the value-weighted returns for other firms in the same one-digit, three-digit, and four-digit SIC industry. These results suggest that CEO pay is more closely linked to broad industry definitions than to narrow industry definitions. In fact, interpreting the market return as our broadest industry definition, the regressions in Tables 1 and

? In keeping with the discussion in footno:e 6, the economic magnitude of the industry adjustment implied by column (2) is not large. In particular, a median-paid CEO in a median-size firm receives ten cents for each $\$ 1,000$ of increased sharcholder wealth when his furm's return is $20 \%$ and the industry return is zero, but receives only six cents per $\$ 1,000$ when both his firm and the industry realize reums of $20 \%$. 


\section{TABLE 2}

Coefficients of Ordinary Least Squares Regressions of $\Delta \ln$ (CEO Salary + Bonus) on Sharcholder Retum, Industry Retum, and Market Retum for Threc Altemative Industry Definitions (1-statistics in parentheses)

\begin{tabular}{|c|c|c|c|c|c|c|}
\hline \multirow{3}{*}{$\begin{array}{l}\text { Independent } \\
\text { Variable }\end{array}$} & & \multicolumn{5}{|c|}{ Regression Cocfficients } \\
\hline & & \multicolumn{5}{|c|}{ Dependent Variable is $\Delta \ln ($ CEO Salary + Bonus) } \\
\hline & (1) & (2) & (3) & (4) & $(5)$ & $(0)$ \\
\hline Intercept & .064 & .051 & .050 & .069 & .068 & .068 \\
\hline $\begin{array}{l}\text { Firm's Ratc } \\
\text { of Retum }\end{array}$ & $\begin{array}{l}.1850 \\
(20.6)\end{array}$ & $\begin{array}{l}.1722 \\
(18.7)\end{array}$ & $\begin{array}{l}.1637 \\
(18.4)\end{array}$ & $\begin{array}{l}.1855 \\
(20.7)\end{array}$ & $\begin{array}{l}.1810 \\
(19.5)\end{array}$ & $\begin{array}{l}.1771 \\
(19.5)\end{array}$ \\
\hline $\begin{array}{l}\text { 1-Digit SIC Industry } \\
\text { Rate of Retum }\end{array}$ & $\begin{array}{l}-.1266 \\
(-7.1)\end{array}$ & 一 & - & $\begin{array}{l}-.0554 \\
(-2.0)\end{array}$ & - & - \\
\hline $\begin{array}{l}\text { 3-Digit SiC Industry } \\
\text { Rate of Return }\end{array}$ & 一 & $\begin{array}{c}-.0452 \\
(-3.5)\end{array}$ & 一 & - & $\begin{array}{l}-.0018 \\
(-0.1)\end{array}$ & 一 \\
\hline $\begin{array}{l}\text { 4-Digit SIC Industry } \\
\text { Rate of Return }\end{array}$ & - & - & $\begin{array}{l}-.0303 \\
(-2.8)\end{array}$ & - & - & $\begin{array}{r}-.0019 \\
(-0.2)\end{array}$ \\
\hline $\begin{array}{l}\text { Valuc-Wcighted Market } \\
\text { Rate of Return }\end{array}$ & - & - & 一 & $\begin{array}{l}-.1027 \\
(-3.4)\end{array}$ & $\begin{array}{l}-.1462 \\
(-6.6)\end{array}$ & $\begin{array}{r}-.1444 \\
(-6.9)\end{array}$ \\
\hline Sample Size & 7.757 & 7.687 & 7.429 & 7,757 & 7.687 & 7,429 \\
\hline$R^{2}$ & .0528 & $.0 \div 83$ & .0479 & .0542 & .0536 & .0539 \\
\hline
\end{tabular}

Note: The sample is constructed from longitudinal data reported in Forbes on 1.668 CEOs serving in 1.049 fIms from 1974-1986.

2 suggest that the magnitude and significance of the industry coefficient, and the explanatory power of the regression, decline monotonically as the industry becomes more narrowly defined.

The regressions in columns (4), (5), and (6) of Table 2 include market return as an additional explanatory variable and replicate the regression in column (4) of Table 1 for the three alternative industry definitions. The market-return coefficient is negative and significant in all three regressions, indicating that market risks are partially filtered out of executive compensation after controlling for industry returns. Holding market returns constant, however, CEO pay growth is negatively and marginally significantly related to one-digit industry retums, but is not significantly related to three-digit or four-digit industry returns. These results suppor the finding that $C E O$ performance is more likely to be evaluated relative to aggregate market movements than relative to industry movements. An alternative interpretation of these results, however, is that 
firms are rarely engaged in a single industry, in which case our inability to detect an industry effect after controlling for market movements could simply reflect the fact that industry definitions based on a single SIC code for each firm are inappropriate for purposes of relative performance evaluation. Other alternative interpretations based on a connection between the performance of the stock market and conditions in the labor market for CEOs may also be possible.

The RPE hypothesis predicts that CEO pay will be more strongly related to market movements the higher the correlation between the firm's return and the return an the market portfolio. Using CRSP monthly stock returns for NYSE firms, we compute the correlation between firm and market return over each preceding two-year period. We re-estimate the regression in column (3) of Table 1 (CEO pay changes on firm and market return) for the subsamples of observations above and below the median value of this correlation statistic and find coefficients on the market return of -.1775 and -.0916 , respectively. The difference between the coefficients is significant ( $t=-1.8)$. We interpret this result as strong additional support for the RPE hypothesis.

The regressions in Table 1 and Table 2 indicate that CEO salaries and bonuses are partially adjusted for industry-and market-wide stock price movements. This evidence is consistent with the RPE hypothesis. ${ }^{8}$ These results are based only on salaries and bonuses,

8 The cvidence also is consistent with a subtly different hypothesis: CEOs are rewarded for sharcholder retum in excess of the market return because this is the true objective of the shareholders. This latter hypothesis is incorrect, because it confuses the sharcholders' $e x$ ante and ex post objeclives. To understand the distinction between the sharcholders' ex ante and expost objectives, consider the following two-stage model of investment and production. During the investment stage of the model there are two kinds of agents, entreprencurs and investors. Entrepreneurs have ideas but no capital; investors have capital but no ideas. If an cntreprencur receives capital from (at least) one investor, then the entreprencur becomes a CEO, the investor becomes a shareholder, and the production stage of the model begins. The production stage is identical to the model in which $y_{i}=a_{i}+\varepsilon_{i}+\theta$. where $y_{i}$ is now the change in sharcholder wealth (gross of wage payments) at the $i^{\text {th }}$ firm, $\varepsilon_{i}$ is idiosyncratic (that is, completely firm-specific) noise, and $\theta$ is a market-wide shock. (Note that this model docs not allow the CEO's action to affect cither the variance of the firm's returns or its covariance with the market.)

According to the capital-asset pricing model, at the investment stage investors care about the covariance betwcen the firm's return and the market (among other things). But at the production stage, sharcholders at the $i^{\text {th }}$ firm face preciscly the contracting problem described above (in the section entited "Rewarding Executives on Relative Performance"): they have invested their capital and now want 10 make the most of it. Thus, in this model, the covariance between the firm's retum and the market has ex ante relevance (because it helps determine which entrepreneurs will receive capital) but not ex post relevance. 
however, whereas CEOs in fact receive compensation in many additional forms-including stock options, profit-sharing arrangements, stock grants, savings plans, long-term performance plans, and other fringe benefits. These other forms of compensation may also be adjusted for industry and market movements, and it is therefore useful to analyze the CEO's toral compensation and not only the cash component of compensation.

The annual Forbes survey's include data on total compensation as well as on salary and bonus. Unfortunately, although the salary and bonus data are easily verifiable and their definitions have remained constant throughout the sample period, the Forbes data for other components of compensation are neither easily verifiable nor reliable. The most severe problems relate to the largest non-cash component of compensation-stock options. Forbes surveys do not include any stock-option data prior to 1978, and after 1978 the survey's report gains from exercising stock options but do not repor stock options granted during the year. The gains from exercising options are typically associated with options granted five to ten years previously, and therefore using these data imposes serious timing problems.

Columns (1) and (2) of Table 3 report regressions based on the Forbes totalcompensation data, excluding both stock-option grants and the gains from exercising stock options. The definition of total compensation varies somewhat from year to year, but typically includes salary, bonus, value of restricted stock, savings and thrift plans, and other benefits. The one-digit industry coefficient in column (1) is negative and significant, indicating that the CEO's total compensation (exclusive of stock options) is based on industry-relative as well as absolute firm performance. The regression in column (2) suggests that market retums are a more important determinant of total compensation than are industry retums, although the industry coefficient is negative and statistically significant. The results in columns (1) and (2) of Table 3 are qualitatively similar to the results in columns (1) and (4) of Table 2, suggesting that our earlier conclusions are not changed by analyzing broader measures of compensation. 
TABLE 3

Cocfficients of Ordinary Leası Squares Regressions of $\Delta \ln ($ Salary + Bonus) and $\Delta \ln$ (Total Pay) on Firm and Industry Retum for Forbes Sample and for Murphy (1985) Sample of Manufacturing Firms

(t-statistics in parentheses)

Independent

Variable

Regression Coefficients

1,049-Firm Forbes Sample
Dependent Variable:
$\Delta \ln [$ Total Pay]

(I)

(2)
.074

.082

.2048

(17.9)

.2055

(18.0)

$-.1859$

$(-8.2)$

$-.0827$

$(-2.4)$

Value-Weighted Relum

Market Value-Wcighted

Rcium on Common Stock

Sample Size

$\mathrm{R}^{2}$ $-\quad-.1487$

7,757

.0397
7,757

.0415
73-Firm Murphy Sample

Dependent Variable: $\Delta \ln [$ Salary + Bonus] $\Delta \ln [$ Total Pay]

\begin{tabular}{cccc}
\hline$(3)$ & $(4)$ & $(5)$ & $(0)$ \\
.024 & .025 & .031 & .025 \\
.1441 & .1455 & $.199+\cdots$ & .1918 \\
$(7.1)$ & $(7.2)$ & $(5.1)$ & $(4.9)$ \\
-.1533 & -.1089 & -.3282 & -.5670 \\
$(-4.7)$ & $(-1.2)$ & $(-5.2)$ & $(-3.3)$ \\
- & -.0522 & - & .2807 \\
& $(-0.5)$ & & $(1.5)$ \\
997 & 997 & 997 & 997 \\
.0495 & .0498 & .0328 & .0351
\end{tabular}

Notc: Forbes sample constructed from longitudinal data on 1.668 CEOs serving in 1.049 firms from 1974-1986. The Forbes definition of total compensation typically includes salary, bonus, value of restricted stock, savings and thrift plans, and other benefits but docs not include the value of stock options granted or the gains from excrcising slock options. The Murphy (1985) data are based on 173 CEOs serving in 73 large manufacturing firms from 1966 to 1983. Murphy's definition of total compensation includes salary, bonus, value of sesuricied stock, savings and thrift plans, other benefits, and the estimated value of stock oplions granted.

The total-pay variable used in columns (1) and (2) excludes stock options, but a better measure would include the value of stock options granted during the year. Although these data are not available for the Forbes sample, they are available for a longitudinal sample of 73 manufacturing firms first analyzed by Murphy (1985). This sample, constructed from proxy statements, includes data on salaries, bonuses, deferred compensation, stock options, and fringe benefits, and covers 173 CEOs from 1966 through 1983. Total compensation is defined as the sum of salaries, bonuses, fringe benefits, stock options, the face value of deferred compensation, and restricted stock awarded during the year (valued at the year-end stock price). Stock options are valued on the date of grant using a Black-Scholes (1973) valuation formula that allows for continuously paid dividends as described in Murphy (1985). 
Columns (3) through (6) in Table 3 repor coefficients from relative-performance regressions based on the 73-firm sample of manufacturing firms. As a robustness check on our earlier results, we re-estimated the one-digit industry salary-and-bonus regressions reported in Table 2 for the manufacturing firm sample. Column (3) in Table 3 shows that the growth rate of CEO cash compensation is positively related to firm peformance and negatively related to industry performance, cctcris paribus. Neither the industry-nor market-return variables are individually statistically significant in the regression in column (4), although they are joinily significant at the $.01 \%$ level. These results are qualitatively similar to those in columns (1) and (4) of Table 2, indicating that our earlier results are not specific to the particular sample analyzed there.

The industry-return coefficient in column (5) of Table 3 is negative and significant, indicating that the CEO's cotal compensation (including stock option grants) is based on industryrelative as well as absolute firm performance. Column (6) includes market returns as an additional explanatory variable, and shows that CEO pay growth is negatively and significantly related to one-digit industry retums, but positively (and insignificantly) related to market retums. Thus, our earlier finding that CEO performance is more likely to be evaluated relative to aggregate market movements than relative to industry movements is not robust across samples for broader definitions of compensation and industry performance. On the other hand, this finding may simply reflect a high correlation between market performance and one-digit industry performance for manufacturing firms. Indeed, when we re-estimate the regressions in columns (3) through (6) of Table 3 using two-digit industry definitions, we find that market movements are a more important determinant of CEO pay changes than are two-digit industry movements.

As an additional robustness check, we use the Forbes sample of 1,668 CEOs to estimate the levels equation analogous to the first-difference specification repored in Table 2, namely:

$$
\operatorname{In}(\text { CEO Pay })_{i t}=\lambda_{i j}+\alpha(A g C)_{i t}+\beta \sum_{t=1}^{l}(\text { Sharcholder Return })_{i t}+\gamma \sum_{t=1}^{t}(1-\text { Digit Industry Returm })_{i t}
$$

where $\lambda_{i}$ is a separate intercept or "fixed-effect" for the ith CEO, and the furst difference of (6) is (5). Our results are reported in Table 4. 
TABLE 4

Cocficicnts of Ordinary Least Squares Regressions of $\ln$ (CEO Salary + Bonus) on Firm and One-Digit Industry Shareholder Retum for Level and First-Difference Specificauions (1-statistics in parentheses)

\begin{tabular}{|c|c|c|c|c|}
\hline \multirow[b]{2}{*}{$\begin{array}{l}\text { Independent } \\
\text { Variable }\end{array}$} & \multicolumn{4}{|c|}{ Dependent Variable in 1000s of 1986-Dollars } \\
\hline & $\begin{array}{c}\text { Change in } \\
\ln (\text { CEO Pay) }\end{array}$ & $\begin{array}{c}\text { Ln } \\
\text { (CEO Pay) }\end{array}$ & $\begin{array}{c}\text { Change in } \\
\text { In(CEO Pay) }\end{array}$ & $\begin{array}{c}\text { Ln } \\
\text { (CEO Pay) }\end{array}$ \\
\hline & (1) & (2) & (3) & (4) \\
\hline Intercept & .064 & (CEO-specific) & .005 & (CEO-specific) \\
\hline Current Stock Retum ( $\left.R_{i i}\right)$ & $\begin{array}{l}.1850 \\
(20.6)\end{array}$ & - & $\begin{array}{l}.1801 \\
(20.1)\end{array}$ & $-\ldots$ \\
\hline Current 1-Digit Industry Retum $\left(\mathrm{I}_{\mathrm{i}}\right)$ & $\begin{array}{l}-.1266 \\
(-7.1)\end{array}$ & - & $\begin{array}{c}-.0740 \\
(.2 .7)\end{array}$ & 一 \\
\hline Time Trend $(t)$ & - & $\begin{array}{l}.0343 \\
(15.5)\end{array}$ & 一 & $\longrightarrow$ \\
\hline Cumulative Stock Retum $\left(\sum_{\tau=1}^{\ell} R_{i \tau}\right)$ & - & $\begin{array}{l}.1829 \\
(25.0)\end{array}$ & 一 & $\begin{array}{l}.1762 \\
(24.3)\end{array}$ \\
\hline $\begin{array}{l}\text { Cumulative I-Digit } \\
\text { Industry Retum }\end{array}\left(\sum_{\tau=1}^{t} I_{i \tau}\right)$ & - & $\begin{array}{c}-.0011 \\
(-0.1)\end{array}$ & - & $\begin{array}{l}-.0449 \\
(-2.2)\end{array}$ \\
\hline Year Dummics & (no) & (no) & (yes) & (ycs) \\
\hline Sample Size & 7,757 & 9.361 & 7.757 & 9,361 \\
\hline $\mathrm{R}^{2}$ & .0528 & .8926 & .0758 & .8964 \\
\hline
\end{tabular}

Note: The sample is constructed from longiludinal data reporicd in Forbes on 1.668 CEOs serving in 1.049 firms from 1974-1986. Columns (2) and (4) include 1.668 individual inlercepts.

Regression Specification: Level: $\quad \ln \left(w_{\mathrm{i}}\right)=\lambda_{\mathrm{i}}+\alpha \mathrm{t}+\beta \sum_{\tau=1}^{\mathrm{t}} \mathrm{R}_{\mathrm{i} \tau}+\gamma \sum_{\tau=1}^{\mathrm{t}} 1_{\mathrm{i} \tau}+\varepsilon_{\mathrm{it}}$

First Difference: $\quad \Delta \ln \left(w_{i t}\right)=\alpha+\beta R_{i t}+\gamma_{i t}+v_{i t}$

To ease comparison, column (1) of Table 4 repeats the regression reported in column (1) of Table 2. Column (2) of Table 4 reports estimated coefficients from the fixed-effects levels equation, (6). If the levels regression is correctly specified, the time-trend coefficient in column (2) should equal the intercept in column (1), and the coefficients for the cumulative firm and industry stock retums in column (2) should equal the coefficients for shareholder return and industry return in column (1), respectively. In fact, the cumulative-stock-retum coefficient in column (2) of Table 4 is very close to the stock-retum coefficient in column (1), but the 
cumulative-industry-return coefficient in column (2) is insignificant whereas the corresponding coefficient in column (1) is significantly negative. This difference in the industry-return coefficient in columns (1) and (2) suggests the possibility that the model is misspecified.

The first-difference and fixed-effects specifications in columns (1) and (2) of Table 4 control for observable and unobservable individual characteristics that are fixed for a CEO over time, but do not allow for economy-wide shocks that vary from year to year. We allow for these time-effects in columns (3) and (4) by including year dummy variables. A comparison of the first-difference specifications in columns (1) and (3) show's that the rate-of-retum coefficients are again similar, and the industry-retum coefficient in column (3), though smaller in magnitude than the coefficient reported in column (1), remains negative and significant. Comparing the fixedeffects specifications in columns (2) and (4), the cumulative-stock-return coefficient is again essentially unchanged, but the cumulative-industry-return coefficient is negative and significant in column (4), in contrast to its insignificance in column (2). Thus, including ycar dummies appears to resolve the discrepancy between the first-difference and fixed-effects specifications.

\section{Comparison with Previous Research}

Antle and Smith (1986) conducted a careful cxamination of the relation between CEO salary and bonus and industry rates of retum but found no evidence that two-digit industry risk is filtered out of executive cash compensation contracts. ${ }^{9}$ In contrast, we find that industry risk is partially filtered out of contracts (although the effect diminishes when we include market movements as well). In an attempt to reconcile these conflicting findings, we investigated several differences between the Antle-Smith methodology and our own. First, whereas our regression specification relates changes in compensation to absolute and industry stock returns,

$9^{\cdots-}$ Antle and Smith (1986). Table 6B. Although Antle and Smith Iind no relation between salary and bonus and industry retums, they do document a weak relation between industry retums and a broader definition of compensation that includes the net returns on inside stockholdings. They measure these net retums on inside stockholdings as the change in the value of stockholdings minus the change in the value of the S\&P 500 porfolio. Thus, their results may be driven by conelations between industry reums and the S\&P porfolio. 
TABLE 5

Coefficients of Ordinary Least Squares Regressions of $\triangle \mathrm{In}$ (CEO Salary + Bonus) on $\Delta$ (Shareholder Return), $\Delta$ (Industry Return), $\Delta$ (Return on Assets), and $\Delta$ (2-Digit Industry Retum on Assets) for Full 1,668-CEO Sample, CEOs in Tliree Industries, and CEOs in 26 Firms

(1-statistics in parentheses)

\begin{tabular}{|c|c|c|c|c|c|c|}
\hline \multirow[t]{3}{*}{$\begin{array}{l}\text { Independent } \\
\text { Variable }\end{array}$} & \multicolumn{6}{|c|}{ Dependent Variable is $\triangle \ln$ (CEO Salary + Bonus) } \\
\hline & \multicolumn{2}{|c|}{$\begin{array}{l}\text { Full Forbes } \\
\text { Sample }\end{array}$} & \multicolumn{2}{|c|}{$\begin{array}{l}\text { Three Antle-Smith } \\
\text { Industries }\end{array}$} & \multicolumn{2}{|c|}{$\begin{array}{l}26 \text { Antle-Smith } \\
\text { Firms }\end{array}$} \\
\hline & (1) & (2) & (3) & (4) & (5) & (6) \\
\hline Intercept & .065 & .066 & .061 & .060 & .051 & .048 \\
\hline $\begin{array}{l}\text { Change in Firm's } \\
\text { Shareholder Retum }\end{array}$ & $\begin{array}{l}.0731 \\
(11.2)\end{array}$ & $\begin{array}{l}.0583 \\
(8.9)\end{array}$ & $\begin{array}{l}.0646 \\
(3.6)\end{array}$ & $\begin{array}{l}.0436 \\
(2.5)\end{array}$ & $\begin{array}{r}-.0431 \\
(1.2)\end{array}$ & $\begin{array}{r}-.0114 \\
(-0.3)\end{array}$ \\
\hline $\begin{array}{l}\text { Change in 2-Digit } \\
\text { Industry Return }\end{array}$ & $\begin{array}{l}-.1071 \\
(-11.0)\end{array}$ & $\begin{array}{l}-.0828 \\
(-8.4)\end{array}$ & $\begin{array}{c}-.1494 \\
(-5.5)\end{array}$ & $\begin{array}{l}-.0738 \\
(-2.6)\end{array}$ & $\begin{array}{l}-1370 \\
(-2.5)\end{array}$ & $\begin{array}{l}-.0026 \\
(-0.0)\end{array}$ \\
\hline $\begin{array}{l}\text { Change in Firm's } \\
\text { Retum on Assets }\end{array}$ & - & $\begin{array}{l}1.220 \\
(15.2)\end{array}$ & - & $\begin{array}{l}1.590 \\
(8.0)\end{array}$ & - & $\begin{array}{l}3.426 \\
(7.1)\end{array}$ \\
\hline $\begin{array}{l}\text { Change in 2-Digit } \\
\text { Industry Retum on Assets }\end{array}$ & - & $\begin{array}{l}.3730 \\
(2.0)\end{array}$ & - & $\begin{array}{l}1.804 \\
(3.3)\end{array}$ & - & $\begin{array}{l}1.682 \\
(2.2)\end{array}$ \\
\hline Sample Size & 7,693 & 7.468 & 1,079 & 1,059 & 247 & 247 \\
\hline $\mathrm{R}^{2}$ & .0196 & .0539 & .0273 & .1036 & .0264 & .2162 \\
\hline
\end{tabular}

Note: Full sample and subsamples constructed from longitudinal data reported in Forbes on 1.668 CEOs serving in 1.049 firms from 1974-1986. The three-industry subsample includes 218 CEOs serving in 135 chemical ( $S I C=28$ ), electronics $(S I C=36$ ) and transportation (SIC=37) firms. The 26-firm subsample includes 44 CEOs.

the Antle-Smith specification relates pay changes to changes in absolute and industry stock and accounting returns. Also, whereas our sample pools data from over 1,000 firms in 58 two-digit SIC industries, the Antle-Smith results are based on separate regressions for 39 firms in three industries.

Column (1) of Table 5 reports results from relative-performance regressions using our data and the Antle-Smith specification,

$$
\Delta \operatorname{In}(\text { CEO Pay })=\alpha+\beta \Delta(\text { Shareholder Reiurn })+\gamma \Delta(2-\text { Digit Industry Retum })
$$

The coefficient on the change in shareholder return is positive and significant, indicating that CEOs are rewarded for taking actions that increase the value of their firm, ceteris paribus. Moreover, the coefficient on the change in industry return is negative and significant, indicating 
that boards of directors adjust for industry shocks when revising the CEO's compensation. This evidence is consistent with the RPE hypothesis, and indicates that specification differences do not explain the difference between our results and Antle and Smith's. Our specification does, however, have more explanatory pow'er than the Antle-Smith specification, with $R^{2}=.0496$ in column (2) of Table 1, compared to $\mathrm{R}^{2}=.0196$ in column (1) of Table $5 .{ }^{10}$

Our results in Tables 1 through 4 are based on pooled cross-sectional time-series data, whereas Antle and Smith report scparate regressions for each firm. In a further attempt to replicate their results, we estimate the regression in column (1) of Table 5 separately for the 690 firms in our sample that had six or more usable obscrvations. The average and median t-statistics associated with the coefficients on the change in industry tetum in these fim-specific regressions are -0.39 and -0.37 , respectively. Two-thirds (450) of the 690 estimated cocfincients are less than zero, and $89(13 \%)$ of the associated t-statistics are less than -1.8. The cstimated coefficients are based on varying degrecs of freedom and it is therefore difficult to test the joint significance of the individual coefficients. As a whole, however, these firm-specific regressions provide fairly strong support for the RPE hypothesis.

It seems likely that the use of RPE varies actoss industries, and it is possible that the particular firms in the three industries analyzed by Antle and Smith (electronics, aerospace, and chemical companies) are for some reason characterized by a lack of rclative-performance evaluation. Column (3) of Table 5 reports coefficients from a regression of pay growth on changes in firm and industry ratcs of return for CEOs in the three industries cxamined by Antle and Smith: chemicals and pharmaceuticals (SIC code 28), electric machinery and equipment (SIC

10 Our specification in (5) restricts the coefricients on lagged shareholder and industry returns to be zero, whereas the Antle-Smith specification (7) implicily restricts these cocfficients to be equal in magnitude and opposite in sign to the analogous coefficients on the contemporaneous performance variables. The Appendix presents results of both first-difference and fixed-effects (level) regressions of compensation on performance and lagged pefformance. The results in columns (1) and (3) suggest that changes in CEO pay are positively related to shareholder retum and (10 a much smaller degree) lagged shareholder return. In addition, the resulis-in column (3). for example-show that pay changes are negatively related 10 contemporancous industry retum, but are positively related to lagged industry retum. The estimated cocfficients in the associated pay-levels regression in column (4) suggest that misppecification is not the cause of this perpiexing result. Column (4) docs, however, provide an alternative statement of the result: although curtent and lagged retums are imporant determinants of the level of pay, we find suppor for the RPE hypothesis with respect to current but not lagged industry reiurns. 
code 36), and transportation (SIC code 37). ${ }^{11}$ The industry-return coefficient in column (3) is negative and significant $(t=-5.5)$, suggesting that the specific industries analyzed by Antle and Smith do not account for the difference in our results. Twenty-six of the 39 Antle-Smith sample firms are included in our data, and column (5) of Table 5 reports RPE regressions for this 26 firm subsample. (Most of the 13 remaining firms were delisted or merged prior to the beginning of our sample.) The industry-return coefficient is again negative and significant; thus, the difference between our results and Antle and Smith's does not appear to be due to differences between the two samples of firms.

In addition to stock performance, the Ande-Smith specification also includes changes in firm and industry return on assets. Columns (2), (4), and (6) of Table 5 replicate the AntleSmith specification (including return on assets) for the Forbes sample, the three-industry sample, and 26-firm sample, respectively. ${ }^{12}$ After controlling for accounting returns, the change in the industry-stock-retum coefficient is negative and significant for the full sample in column (2) and the three-industry sample in column (4), but is insignificant for the 26 -firm sample in column (6). ${ }^{13}$ Therefore, a combination of differences in sample size and composition and in regression specification seems to reconcile our results with Antle and Smith's. ${ }^{14}$

Although Jensen and Murphy (1990) do not directly test the RPE hypothesis, they analyze Forbes compensation data and conclude that changes in CEO pay are much more closely related to changes in sharcholder wealth than to changes in shareholder wealth measured relative

11 The Ante-Smith sample is from the aircraft-manufacturing subset of the two-digit transporation industry (which also includes automotive firms) and the chemical subset of the two-digit chemical and pharmaceuticals industry, but their industry-relative reums are based on the more broadly defined two-digit industries.

12 Return on assets is constructed from Compustat data and is defined as the sum of after-tax income (before extraordinary items), interest, and interest tax shields, divided by total assets. Industry retum on assets is defined as the asset-weighted-average retum on assets for all other furms in the same two-digit industry.

13 The retum on assets and industry retum on assets variables are positive and significant in columns (2). (4). and $(6)$ of Table 5. Therefore, although our results support the RPE hypothesis with respect to the principal's objective (shareholder reum), we do not find evidence for RPE with respect to accounting retums.

14 There are other differences between the Anve-Smith methodology and ours that may have some bearing on the difference in results. Ande and Smith average the after-tax salary and bonus of the three highest-paid executives, for example, and their data cover an earlier time period (1946-77). Also, whereas our measure of industry returns is the value-weighted average retum in the industry. Antle and Smith calculate weighted-average industry returns in which the weight for each firm in the two-digit industry is the correlation coefficient betwcen the returns of that firm and the sample furm. 
to the market or two-digit industry. In the spirit of their specification, we estimate a regression of the change in CEO pay on the change in shareholder wealth and the change in wealth the shareholders would have received had they invested in an industry portfolio rather than in the sample firm. Shareholder-wealth changes are measured as $R_{1} V_{t-1}$, where $R_{t}$ is shareholder return and $V_{t-1}$ is the firm value at the end of the previous year. Industry-wealth changes are measured as $I_{1} V_{t-1}$, where $V_{t-1}$ is as before and $I_{l}$ is the rate of return on a value-weighted portfolio of all other firms in the two-digit industry. The estimated coefficients from this regression are

$$
\Delta(\text { Salan' and Bonus })=32.1+\underset{(t=6.3)}{.0133\left(R_{t} V_{t-1}\right)}+\underset{(t=1.0)}{.0021\left(l_{1} V_{t-1}\right) .}
$$

The coefficient on the change in industry wealth in (8) is positive and insignificant. This specification therefore yields no support for the RPE hypothesis. The regression in ( 8 ) differs from column (2) of Table 1 for two reasons. First, the dependent variable in (8) is the change in salary and bonus, as opposed to the change in the logarithm of salary and bonus (that is, the growth-rate of pay) in Table 1. Second, the independent variables (excluding the intercept) in (8) differ from those in (5) because the former are multiplied by $V_{1-1}$, the beginning-of-period market value. Both of these differences appear to have some bearing on the difference between our results in (8) and Table 1, although the latter seems to be the more important of the two. ${ }^{15}$ In related work (Gibbons and Murphy 1989) we show that the rate-of-return specification of the independent variables reduces the impact of heterogencity by firm size in pooled regressions.

I5 Re-estimating (8) with the rate of grow'th of CEO pay as the dependent variable yields

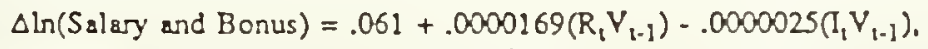

$$
\begin{aligned}
& (t=6.4) \quad(t=-1.0)
\end{aligned}
$$

and re-estimating (8) with rates of return instead of wealth changes as independent variables yiclds

$$
\begin{array}{r}
\Delta(S \text { alary and Bonus })=28.4+110.7\left(R_{J}\right)-38.89\left(I_{\nu}\right) . \\
(t=15.0) \quad(t=-3.2)
\end{array}
$$

Both of these regressions yield negative point estimates for the industry variable, but the industry cocfficient is significant only in the second case, where wealth changes are replaced by rates of return. 


\section{Relative Performance and CEO Turnover}

An important part of the contractual arrangement between a CEO and his board of directors (an arrangement that maybe either explicit or implicit) is a specification of the conditions under which the CEO will be encouraged or forced to leave office. The CEO succession process serves a variety of purposes, including bringing "new blood" into the helm, replacing tired or unhealthy CEOs, and providing promotion opportunities for other executives in the organization.

We focus on one important aspect of the succession process that provides direct incentives for the current CEO: the threat of dismissal for poor performance. Implicit contracts linking dismissal to changes in shareholder wealth generate incentives for CEOs to take actions that increase shareholder wealth. As in the case of compensation, however, basing dismissals on absolute performance subjects CEOs to uncertainties associated with industry and market stockprice movements. Therefore, as long as CEOs cannot take actions to affect the measured performance of the other firms in the industry or market, basing dismissals on relative performance yields incentives to increase shareholder wealth while filtering out exogenous risks.

CEOs are rarely openly fired from their positions; Weisbach (1988), for example, analyzed $286 \mathrm{CEO}$ changes over ten years and found only nine cases in which boards mentioned performance as a reason why the CEO was replaced. CEO turnover, however, occurs frequently: over half $(1,000)$ of the $1,914 \mathrm{CEO}$ in our sample for whom performance data are available left office during the 1974-86 sample period. We estimate the importance of RPE in CEO dismissal decisions by estimating the effect of firm, industry, and market performance on the probability that a CEO will soon leave office. In particular, we estimate the following logistic regression:

$$
\ln \left(\frac{\text { Prob[Tumover }]}{1-\text { Prob[Tumover }]}\right)=\alpha+\beta(\text { Sharcholder Retum })+\gamma(1 \text {-Digit Industry and/or Market Retum })
$$


TABLE 6

Estimated Logistic Models Predicting CEO Tumover Using Shareholder, Industry, and Market Rates of Return

(asy'mplotic l-statistics in parcntheses)

Independent Variable

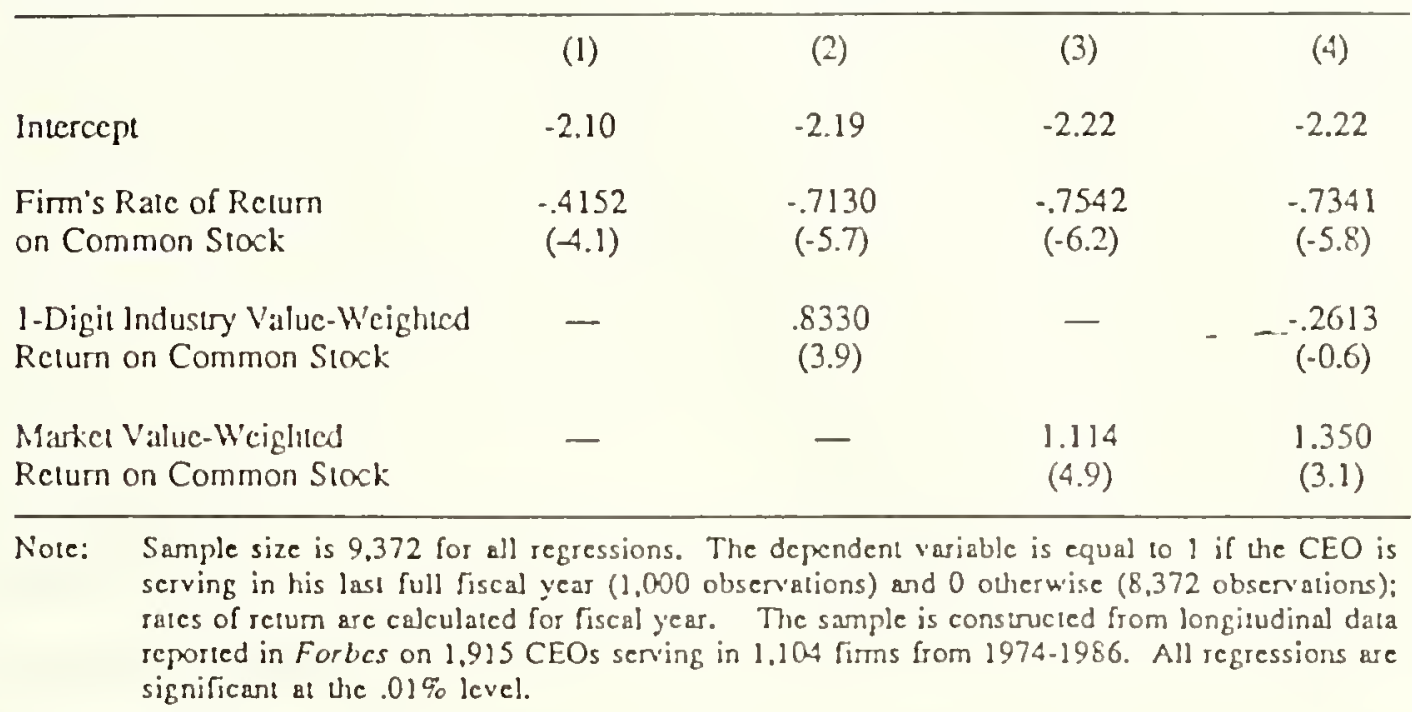

The dependent variable equals one if the CEO is serving in his last full fiscal year, and zero otherwise. ${ }^{16}$ The theory of relative performance evaluation predicts that CEOs are more likely to be dismissed following bad years in the frm, but are less likely to leave following bad years in the industry and market, cetcris paribus. We interpret $\beta<0$ and $\gamma>0$ as evidence that, although explicit dismissals are rare, many instances of tumover are in fact dismissals and are based on relative performance.

Table 6 repors coefficients from logistic regressions predicting the probability of CEO turnover as a function of shareholder, industry, and market rates of return. Column (1) shows that, unconditional on industry and market performance, the probability that a CEO is serving in his last full fiscal year is negatively and significantly related to the rate of retum realized by shareholders during that year. Converting the regression coefficients into estimated tumover

16 The 1988 Forbes survey was examined to identify CEOs whose last fiscal year was 1986. The final CEOyear for firms leaving the Forbes survey is excluded, since we cannot deicrmine whether or nol this is the last year for that CEO. A total of 582 fims were deleted from the Forbes survey's during the $1974-86$ sample period. Of these, 293 are still "going concerns" as of 1987,214 were acquired by or merged with another firm, and 35 liquidated, went bankrupt, or went private. Current status data are unavailable for 40 of the 582 furms. 
probabilities, the regression in column (1) implies that a CEO has a .109 turnover probability in y'ears when the firm earns a zero return, but a .131 dismissal probability in years when the firm realizes a $-50 \%$ return. ${ }^{17}$

Columns (2) and (3) of Table 6 show that turnover probabilities are negatively and significantly related to shareholder return, but positively and significantly related to returns in the one-digit industry and market, cetcris paribus. The regression in column (3) implies, for example, that a CEO has a .098 tumover probability in years when both the firm and the market earn a zero return. The same CEO has a .137 turnover probability when the firm earns a $-50 \%$ return while the market retum is zero, but only a .083 turnover probability in years when both the firm and market earn a $-50 \%$ return.

Column (4) in Table 6 includes both industry and market returns. As in column (3), the market-retum coefficient in column (4) is positive and statistically significant, although it is much reduced in size. The industry-return coefficient in column (4) remains positive but is no longer significant after controlling for market-wide stock-price movements. We also re-estimated columns (2) and (4) using the two-digit, three-digit, and four-digit alternative indusiry definitions. Consistent with our earlier results on compensation, we find that the magnitude of the industry coefficient declines monotonically as the industry becomes more narrowly defined (although the results for one-digit and two-digit industries are virtually identical). Thus, our results suggest that CEO turnover policy is more likely to control for aggregate market movements than to control for industry movements.

CEOs leave office for a variety of reasons and usually leave their position only after reaching normal retirement age; a third of the CEOs in our sample left when they were 64 or 65 , and more than half left between the ages of 62 and 66 . We anempt to exclude normal retirements by re-estimating the logit regressions in Table 6 for the subset of CEOs younger than 64 . Our 


\section{TABLE 7}

Estimated Logistic Models Predicting CEO Tumover Using Current and Lagged Shareholder. 1-Digit SIC Industry, and Market Rates of Return

(asy'mptotic t-statistics in parentheses)

\begin{tabular}{|c|c|c|c|c|c|}
\hline \multirow[t]{2}{*}{$\begin{array}{l}\text { Indepcondent } \\
\text { Variable }\end{array}$} & \multicolumn{5}{|c|}{ Cocfficient Estimates } \\
\hline & (1) & (2) & (3) & & (4) \\
\hline Intercept & -2.10 & -2.21 & -2.26 & & -2.25 \\
\hline Current Stock Return & $\begin{array}{r}-.3499 \\
(-3.4)\end{array}$ & $\begin{array}{c}-.6531 \\
(-5.2)\end{array}$ & $\begin{array}{c}-.6981 \\
(-5.7)\end{array}$ & & $\begin{array}{l}-.6747 \\
(-5.3)\end{array}$ \\
\hline Lagged Stock: Return & $\begin{array}{c}-.2660 \\
(-2.7)\end{array}$ & $\begin{array}{c}-.4114 \\
(-3.3)\end{array}$ & $\begin{array}{c}-.4122 \\
(-3.4)\end{array}$ & & $\begin{array}{r}-.4295 \\
--(-3.4)\end{array}$ \\
\hline $\begin{array}{l}\text { Current 1-Digit } \\
\text { Industry Return }\end{array}$ & - & $\begin{array}{l}.8253 \\
(3.9)\end{array}$ & - & & $\begin{array}{l}-.2905 \\
(-0.7)\end{array}$ \\
\hline $\begin{array}{l}\text { Lagged 1-Digit } \\
\text { Industry Return }\end{array}$ & - & $\begin{array}{l}.3263 \\
(1.6)\end{array}$ & 一 & & $\begin{array}{c}.2377 \\
(0.6)\end{array}$ \\
\hline Current Market Retum & - & - & $\begin{array}{l}1.117 \\
(4.8)\end{array}$ & & $\begin{array}{r}1.379 \\
(3.1)\end{array}$ \\
\hline Lagged Market Rctum & - & 一 & $\begin{array}{l}.3835 \\
(1.7)\end{array}$ & & $\begin{array}{l}.1924 \\
(0.4)\end{array}$ \\
\hline
\end{tabular}

Notc: Sampic size is 9.291 for all regressions. The dependent variable is equal 10 i if the CEO is sering in his last full fiscal year (992 observations) and 0 otherwise ( 8.299 obseriations): rates of retum are calculated for fiscal year. The sample is constructed from longitudinal data reported in Forbes on 1.896 CEOs sering in 1.092 firms from 1974-1986. Als regressions ase significant at the .0150 ievel.

results for the younger subsample are qualitatively similar to the results for the full sample, although the asymptotic t-statistics and significance levels tend to be higher for the subsample.

Many factors can affect stock prices in addition to industry' and market movements, and boards of directors may plausibly require more than a single bad year before forcing or encouraging a CEO to leave office. Table 7 repors coefficients from logit regressions predicting the probability of CEO tumover as a function of current and lagged shareholder, industry, and market rates of retum. The results in Table 7 are very similar to the results in Table 6 , and the effects of contemporaneous pefformance on tumover probability are uniformly greater than are the effects of lagged performance. We also re-estimated the regressions in Table 7 after incorporating an additional lagged performance variable (namely, performance measured iwo years before the CEO's final fiscal year) and obtained similar results. These results are 
consistent with the findings of Warner, Watts, and Wruck (1988) and Weisbach, who concluded that decisions to replace CEOs are based on relatively recent performance data.

\section{Comparison with Previous Research}

Warner, Watts, and Wruck estimated logit regressions for 87 CEO changes and found that the probability of CEO turnover is negatively related to contemporaneous shareholder retum and positively related to contemporaneous market retum, whereas the relation between turnover probability and past performance is generally insignificant. Consistent with our results, Warner, Watts, and Wruck found that turnover is unrelated to industry performance after controlling for market performance. Although their sample is much smaller than ours (which is based on 1,000 CEO changes), the Warner-Watts-Wruck data may be less noisy than ours since they measure performance from the date when the CEO change was announced rather than over the preceding fiscal year. ${ }^{18}$ The similarity of our results and theirs suggests that our evidence supporing RPE in CEO turnover policy is robust to these potentially imporant timing problems.

Several studies that did not directly test the RPE hypothesis nevertheless provide results that are consistent with our findings. Coughlan and Schmidt (1985) found an inverse relation between CEO turnover and abnormal stock-price performance (estimated as the cumulative annual residual from the market model), and Weisbach (1988) obtained similar results by measuring performance as shareholder retum minus the return on a value-weighted market porfolio. In addition, Morck, Shleifer, and Vishny (1988) found that the probability that the entire top-management team leaves is negatively related to abnormal performance minus abnormal performance in the industry.

18 In addition, Wamer-Watts-Wruck also excluded cases in which the CEO title changed hands but the topmanagement team remained intact (for example, the chairman-CEO remained chaiman but passed the CEO title to the president). We have no way of identifying these cases in our data. 


\section{Conclusion}

Rewarding top-level executives based on performance measured relative to aggregate performance in the industry or market creates incentives to take actions increasing shareholder wealth while insuring executives against the vagaries of the stock and product markets that are beyond their control. We expect RPE to be a common feature of implicit CEO compensation and dismissal contracts because the potential benefit of filtering out common uncertainty is high, the cost of measuring the performance of other firms is small, and opponunities for sabotage and collusive shirking are limited.

The empirical evidence presented above suppors the RPE hypothesis: the revision in a CEO's pay and the probability that a CEO remains in his position for the following year are positively and significantly related to firm performance, but are negatively and significantly related to industry and market pefformance, ceteris paribus. Our results also suggest that CEO performance is more likely to be evaluated relative to aggregate market movements than relative to industry movements, although our inability to detect an industry effect after controlling for market movements may reflect the inappropriateness of industry definitions based on SIC codes for purposes of relative performance evaluation.

The theoretical justification for rewarding top-level exccutives on the basis of relative performance is strong, and therefore the fact that previous research has failed to detect a significant relative-performance effect has been troublesome. The results in this paper begin to resolve the puzzle by documenting a significant negative relation between CEO compensation and industry and market performance, but more work remains to be done before the data can be said to provide completely convincing support for the RPE hypothesis. Although our results support the RPE hypothesis with respect to current shareholder return, we do not find evidence for RPE with respect to changes in shareholder wealth (equation 8), lagged shareholder return 
(Appendix), or accounting returns (Table 5). Finally, we have made no attempt to distinguish between the incentive and learning versions of the RPE hypothesis.

Although the theory of relative performance evaluation predicts that optimal contracts will protect CEOs from industry and market shocks, there are many aspects of a CEO's wealth that are not protected from industry and market movements in stock prices. The gains and losses associated with stock options and inside stockholdings, for example, depend solely on the firm's absolute stock-market performance and not on performance measured relative to the industry or market. Therefore, although the CEO's compensation and probability of dismissalare partially insured against industry and market risk, other potentially more important components of his wealth are not.

It would be straightforward, however, to design a compensation plan that duplicates the rewards and losses from stock ownership or stock options after adjusting for industry- or market-wide stock movements, and it is puzzling that few firms have adopted such explicit RPE compensation systems. It may be that current stock-option and restricted-stock plans are easy to administer and offer tax advantages, and that the costs of switching to new systems outweigh the potential benefits. Altematively, the distoned incentives induced by RPE-in terms of sabotage, collusion, choice of reference group, or production externalities-may in fact be important for top-level managers. Determining why RPE is not more comprehensive is an important goal for future research. 


\section{References}

Antle, Rick, and Abbie Smith. 1986. "An Empirical Investigation of the Relative Performance Evaluation of Corporate Executives." Journal of Accounting Research, Vol. 24, No. 1 (Spring), pp. 1-39.

Baiman, Stanley and Joel Demski. 1980. "Economically Optimal Performance Evaluation and Control Systems." Journal of Accounting Research, Vol. 18 (Supplement), pp. 184-220.

Black, Fischer and Myron Scholes. 1973. The Pricing of Options and Corporate Liabilities." Journal of Political Economy, Vol. 81, No. 3 (May/June), pp. 637-54.

Carmichael, H. Lorne. 1988. "Incentives in Academia: Why Is There Tenure?" Journal of Political Economy, Vol. 96, No. 3 (June), pp. 453-72.

Coughlan, Anne T. and Ronald M. Schmidt. 1985. "Executive Compensation, Management Turnover, and Firm Performance: An Empirical Investigation." Journal of Accounting and Economics, Vol. 7. Nos. 1-3 (April), pp. 43-66.

Dye, Ronald A. 1984. "The Trouble with Tournaments." Economic Inquiry, Vol. 22, No. 1 (January), pp. 147-49.

Dye, Ronald A. 1988. "Relative Performance Evaluation and Project Selection." Unpublished paper, Norhwestern University.

Gibbons, Robert, and Kevin J. Murphy. 1989. "Optimal Incentive Contracts in the Presence of Career Concerns: Theory and Evidence." Unpublished paper, Massachusetts Institute of Technology.

Holmström, Bengt. 1979. "Moral Hazard and Observability." Bell Journal of Economics, Vol. 10, No. 1 (Spring), pp. 74-91.

Holmström, Bengt. 1982. "Moral Hazard in Teams." Bell Journal of Economics, Vol. 13, No. 2 (Autumn), pp. 324-40.

Jensen, Michael C., and Kevin J. Murphy. 1990. "Performance Pay and Top-Management Incentives." Journal of Political Economy (forthcoming).

Lazear, Edward P. 1987. "Pay Equality and Industrial Politics." Unpublished paper, Hoover Institution.

Lazear, Edward P., and Sherwin Rosen. 1981. "Rank-Order Toumaments as Optimum Labor Contracts." Journal of Political Economy, Vol. 89, No. 5 (October), pp. 841-64.

Mood, Alexander, and Franklin Graybill. 1963. Introduction to the Theory of Statistics, 2nd Edition. New York: McGraw-Hill.

Mookherjee, Dilip. 1984. "Optimal Incentive Schemes with Many Agents." Review of Economic Studies, Vol. 51, No. 3 (July), pp. 433-46.

Morck, Randall, Andrei Shleifer, and Robert W. Vishny. 1988. "Alternative Mechanisms for Corporate Control." Unpublished paper, NBER. 
Murphy, Kevin J. 1985. "Corporate Performance and Managerial Remuneration: An Empirical Analysis." Journal of Accounting and Economics, Vol. 7, Nos. 1-3 (April), pp. 11-42.

Stigler, George J. 1964. "A Theory of Oligopoly." Journal of Political Economy, Vol. 72, No. 1 (February).

Vancil, Richard F. 1987. Passing the Baton: Managing the Process of CEO Succession. Boston: Harvard Business School Press.

Warner, Jerold B., Ross L. Watts, and Karen H. Wruck. 1988. "Stock Prices, Event Prediction, and Event Studies: An Examination of Top Management Changes." Journal of Financial Economics, Vol. 20, No. 1/2 (January/March), pp. 461-92.

Weisbach, Michael S. 1988. "Outside Directors and CEO Turnover." Journal of Financial Economics, Vol. 20, No. 1/2 (January/March), pp. 431-60.

Wolfson, Mark. 1985. "Tax, Incentive, and Risk-sharing Issues in the Allocation of Property Rights: The Generalized Lease-or-Buy Problem." Journal of Business, Vol. 58, No. 2 (April), pp. 159-72. 


\section{APPENDIX}

Cocfficicnts of Ordinary Least Squares Regressions of in(CEO Salary + Bonus) on Firm and Industry Sharcholder Return for Level and First-Difference Specifications ( 1 -statisucs in parcntheses)

\begin{tabular}{|c|c|c|c|c|}
\hline \multirow[b]{2}{*}{$\begin{array}{l}\text { Independent } \\
\text { Variable }\end{array}$} & \multicolumn{4}{|c|}{ Dependent Variable in 1000s of 1986-Dollars } \\
\hline & $\begin{array}{c}\text { Cliangc in } \\
\text { In(CEO Pay) }\end{array}$ & $\begin{array}{c}\ln \\
\text { (CEO Pay) }\end{array}$ & $\begin{array}{l}\text { Change in } \\
\text { In(CEO Pay) }\end{array}$ & $\begin{array}{c}\text { In } \\
\text { (CEO Pay) }\end{array}$ \\
\hline & (1) & (2) & (3) & (4) \\
\hline Intercept & .046 & (CEO-specific) & .043 & (CEO-specific) \\
\hline Current Stock Return $\left(\mathrm{R}_{\mathrm{iL}}\right)$ & $\begin{array}{l}.1792 \\
(20.2)\end{array}$ & $\begin{array}{l}.0166 \\
(1.9)\end{array}$ & $\begin{array}{l}.1746 \\
(19.5)\end{array}$ & $\begin{array}{r}.0222 \\
-\quad(2.5)\end{array}$ \\
\hline Lagged Stock Return $\left(R_{i 1-1}\right)$ & $\begin{array}{l}.0284 \\
(3.3)\end{array}$ & - & $\begin{array}{l}.0275 \\
(3.2)\end{array}$ & 一 \\
\hline $\begin{array}{l}\text { Current 1-Digit } \\
\text { Industry Rcturn }\left(l_{i l}\right)\end{array}$ & $\begin{array}{l}-.0893 \\
(-5.0)\end{array}$ & $\begin{array}{l}-.1443 \\
(-9.5)\end{array}$ & $\begin{array}{l}-.0855 \\
(-3.1)\end{array}$ & $\begin{array}{l}-.0636 \\
(-2.3)\end{array}$ \\
\hline $\begin{array}{l}\text { Lagged I-Digit } \\
\text { lndustry Rclurn }\left(l_{i t-1}\right)\end{array}$ & $\begin{array}{l}.0849 \\
(6.1)\end{array}$ & - & $\begin{array}{l}.0584 \\
(2.1)\end{array}$ & $\longrightarrow$ \\
\hline Time Trend (l) & $\longrightarrow$ & $\begin{array}{l}.0256 \\
(10.8)\end{array}$ & - & - \\
\hline Cumulative Stack Relurn $\left(\sum_{\tau=1}^{l} R_{i \tau}\right)$ & - & $\begin{array}{l}.1779 \\
(22.0)\end{array}$ & $\longrightarrow$ & $\begin{array}{l}.1676 \\
(20.8)\end{array}$ \\
\hline $\begin{array}{l}\text { Cumulative l-Digit } \\
\text { Industry Return }\end{array}\left(\sum_{\tau=l}^{t} I_{i \tau}\right)$ & 一 & $\begin{array}{l}.0830 \\
(4.7)\end{array}$ & - & $\begin{array}{r}-.0244 \\
(-1.2)\end{array}$ \\
\hline Ycar Dummics & (no) & (no) & (yes) & (yes) \\
\hline Sample Sizc & 7.696 & 9,361 & 7,696 & 9.361 \\
\hline$R^{2}$ & .0652 & .8941 & .0769 & .8965 \\
\hline
\end{tabular}

Note: The sample is constructed from longitudinal data reponed in Forbes on 1.668 CEOs serving in 1,049 [rms from 1974-1986. Columns (2) and (4) include 1,668 individual inlercepts.

Regression Specification:

$$
\begin{aligned}
& \text { Level: } \quad \ln \left(\omega^{\prime}{ }_{i}\right)=a_{i}+\alpha i+\left(\beta_{0}-\beta_{1}\right) R_{i t}+\beta_{1} \sum_{\tau=1}^{l} R_{i \tau}+\left(\gamma_{0}-\gamma_{1}\right) I_{i t}+\gamma_{1} \sum_{\tau=1}^{l} I_{i \tau}+\varepsilon_{j i} \\
& \text { First Difference: } \quad \Delta \ln \left(w_{i}\right)=\alpha+\beta_{0} R_{i t}-\left(\beta_{0}-\beta_{1}\right) R_{i t-1}+\gamma_{0} I_{i t}-\left(\gamma_{0}-\gamma_{1}\right) I_{i 1-1}+v_{i t}
\end{aligned}
$$


2385005 



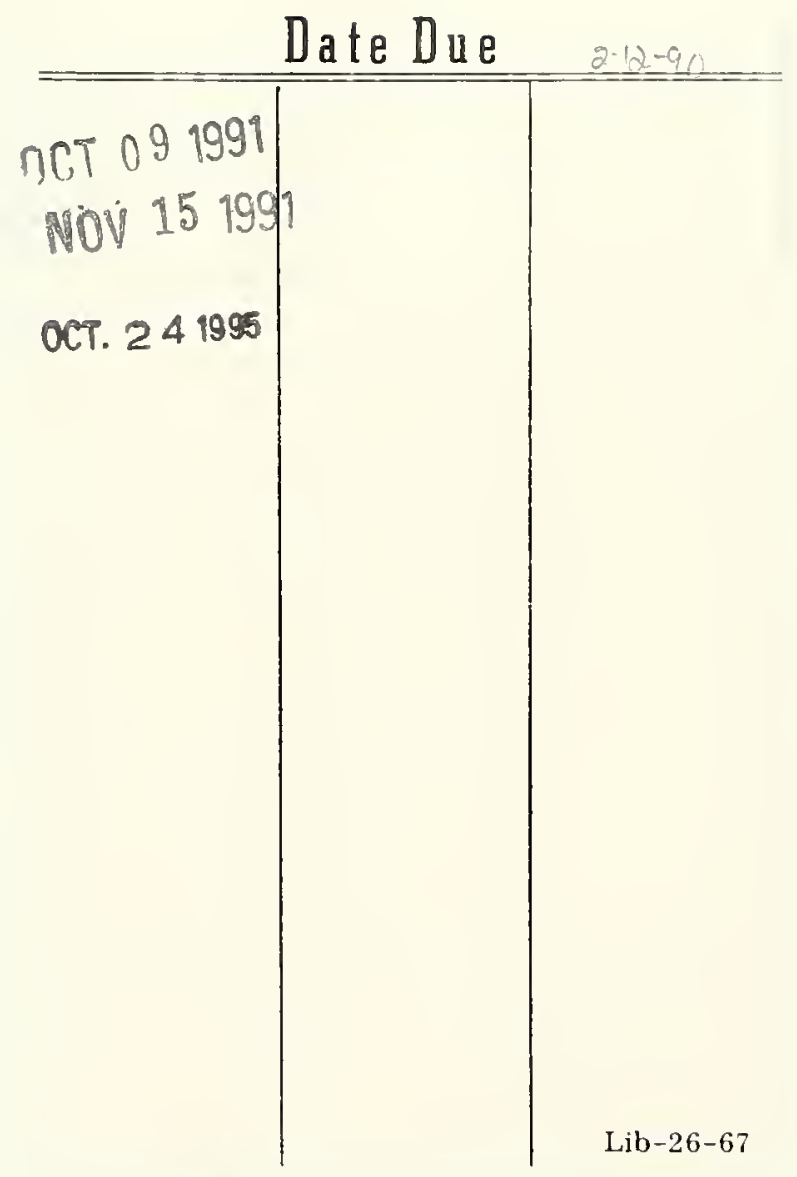




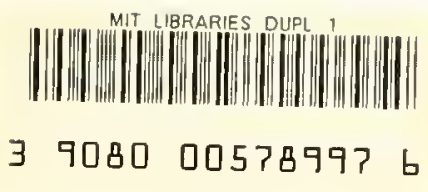


